\begin{abstract}
JUDYTA DWORAS-KULIK
Wydział Prawa, Prawa Kanonicznego i Administracji

Katolickiego Uniwersytetu Lubelskiego Jana Pawła II

ORCID: 0000-0002-1990-5497
\end{abstract}

\title{
DEBATE OVER SECULARISATION OF THE MARRIAGE LAW IN THE SECOND POLISH REPUBLIC
}

Content: - Introduction. - 1. Dispute over the jurisdiction of ecclesiastical courts that have the power to adjudicate on matrimonial cases. -2 . Debate over the personal character of marriage law. -3 . Dispute over the form of marriage celebration. -4 . Dispute over divorce and separation. -5 . Dispute over the jurisdiction in matrimonial cases. - Conclusion

\section{Introduction}

After Poland regained its independence in 1918, in order to maintain legal continuity, the country continued to use the legislation of the former partitioners, so there were three variants of marriage legislation in Poland at the time: secular (Hungarian and German law), mixed, i.e. religious and secular (Austrian law), and religious (law in force in the area of the former Russian Partition - the eastern and central lands of the Second Republic). The system of personal marriage law encompassed five legal areas. ${ }^{1}$

${ }^{1} \mathrm{~J}$. Dworas-Kulık, Przyczyny i skutki legalnej bigamii w Polsce w okresie międzywojennym, in: Pogranicza w historii prawa i myśli polityczno - prawnej, eds. D. Szpoper, P. Dąbrowski, Gdańsk - Olsztyn, GSW 2017, p. 109-110; A. STAWECKA-FIRLEJ, Małżeńskie prawo osobowe ustawodawstw porozbiorowych obowiązujących 
In the south, that is, in the territory of the former Austrian partition, Austrian civil regulations were in force, which introduced the civil form of marriage in special cases, the so-called „civil marriages of necessity” (there was an impediment under canon law that was not known in the general civil code, or it had been removed by dispensation or if it concerned either members of a faith that was not recognised by the State or individuals who declared their non-religiousness. In the former Austrian partition, jurisdiction in matrimonial matters was granted to secular common courts enforcing state legislation. We should also mention the twenty-seven villages of Spiš and Orava, where the Hungarian marriage law of 1894 was in force. Since 1922, the Austrian law allowing a religious form of marriage was also introduced in this area by a decree of the Council of Ministers, resulting in the concurrent existence of two marriage systems and optional civil marriages. The choice of a secular form of marriage by the spouses made it necessary to respect the Hungarian marriage law, while religious marriage was governed by the Austrian law. On the basis of $\$ 5$ point 1 of the regulation referred to above, marriages contracted so far were to be assessed according to the previous regulations. Marriages considered invalid became valid from their beginning as long as the spouses, on the date of entry into force of the decree (1922), remained in conjugal union and their marriage fulfilled the conditions corresponding to those of the Civil Code, which in this case were necessary for the assessment of the personal relations between the spouses. It is worth noting that in Spiš and Orava, by virtue of 1922 regulation, Austrian procedure was applicable.

In the central provinces, after the suppression of the November Uprising, the law of the Kingdom of Poland of 1825, providing for a uniform judiciary system, was repealed and replaced by the 1836 $u k a z$ of Tsar Nicholas I. Individual regulations were introduced for individual confessions recognized by the State, dividing them into

w Rzeczypospilitej Polskiej w dwudziestoleciu międzywojennym, Prawo. Studia Historyczno-prawne CCCXV (2013), no 2, p. 75-94. 
regulations concerning spouses who were Catholics, Evangelicals, Orthodox, Eastern Catholics, and mixed marriages. Jurisdiction in matrimonial matters was granted to ecclesiastical courts of each of those confessions. In the case of other faiths, pursuant to $₫ 179$ of the marriage law, they were subject to internal regulations, applicable to a particular religious organisation or association, whereas the judicial competence over their followers was exercised by civil common courts. The fragmentation of the law had an impact on separate conditions necessary for dissolution of marriage for each denomination. Similar legal solutions were in force in the eastern lands. The main difference lay in the preference given to the Orthodox Church and the total subordination of matrimonial jurisdiction to ecclesiastical courts. Civil law adopted the regulations of individual denominations as its own, assigning them the status of state law, which in practice resulted in a complete limitation of supervision over the legal acts taken by the authorities of religious organisations or associations and their members.

In the western provinces civil marriages were in force. All citizens residing in the area of the former Prussian partition were subject to identical regulations, regardless of their religion. Religious rituals were allowed only after a civil marriage certificate was drawn. Jurisdiction in matrimonial cases was exercised exclusively by state courts. ${ }^{2}$

\section{Dispute over the jurisdiction of ecclesiastical courts that have the power to adjudicate on matrimonial cases}

The practice of ecclesiastical courts in the area of civil jurisdiction was contrary to the applicable regulations of civil law, concerning mainly the subject-matter jurisdiction of the court with a competence to adjudicate in a given case, which created a clash between decisions issued by different ecclesiastical courts and, as a result, to mutual

\footnotetext{
2 See: J. Dworas-Kulik, Prawne regulacje dotyczące bigamii $w$ Polsce $w$ latach 1918-1939, Lublin, KUL 2019, p. 20-25; S.M. Grzy bowski, I. Różański, Prawo matżeńskie. Komentarz. Wyciagi z motywów Komisji Kodyfikacyjnej. Tezy polityczne. Wzory, Kraków, Księgarnia Powszechna 1946, p. 1-8.
} 
non-recognition of sentences in cases of inter-faith marriages, and to re-adjudication on the same legal event. The chaos in the field of marriage law was aggravated by the possibility of obtaining a divorce by changing one's confession to another, which then gave the person the right to remarry according to the new religion. This fact was not recognised by the Church of the previous confession of the new spouses, considering the first marriage to be still valid. ${ }^{3}$ Nor did ecclesiastical courts respect the laws which, according to the provisions of state law, should have been applied when ruling on divorce or marriage nullity. Thus, where the basis for a judicial decision was civil legislation, ecclesiastical courts each time ruled in matrimonial matters on the basis of their own religious regulations, while ignoring the state legislation. They did not consider secular marriages to be valid and binding. Disregard for the law and attempts to circumvent it contributed to the creation of so-called "legal bigamy," the effects of which were visible both on the civil and criminal law. ${ }^{4}$

${ }^{3}$ For more on this, see: J. Dworas-Kulik, Prawne regulacje..., p. 99-155; Idem, Prawnokarne aspekty bigamii w Polsce w okresie dwudziestolecia międzywojennego, Roczniki Nauk Prawnych XXVII (2017), no 2, p. 17-39; A. FAstyn, Jurysdykcja sądu konsystorskiego w świetle przepisów prawa matżeńskiego z 1836 r., Czasopismo Prawno - Historyczne LXII (2010), no. 1, p. 111-132; M. Allerhand, Jurysdykcja władz wyznaniowych w sprawach małżenskich, Czasopismo Sędziowskie XI (1937), no 3, p. 113-123, no 4, p. 176-182; H. Św IĄTKOWsKI, Z praktyki sądów konsystorskich, Głos Sądownictwa X (1938), no 2, p. 107-114; Idem, Jeszcze o działalności sądów konsystorskich, Gazeta Sądowa Warszawska LXII (1934), no 5, p. 67-69.

${ }^{4}$ See: J. Dwor As-Kulik, Prawne regulacje..., p. 165-198; Idem, Przyczyny i skutki legalnej bigamii..., p. 111-121; H. Śwıс̨ткоwsкi, Problem legalnej bigamii w Polsce przedwrześniowej, Nowe Prawo (1959), no 10, p. 1150-1158; M. Allerhand, O wpływie orzeczeń $w$ sprawach matżeńskich wydanych przez sady duchowne $w$ b. zaborze rosyjskim na stosunki prawne w innych dzielnicach Rzeczypospolitej Polskiej, Lwów, published by the author 1925; J. GwiAzDomorski, Skuteczność orzeczeń sadów duchownych b. Król. Kongr. W sprawach małżeńskich wobec prawa państwowego, Przegląd Prawa i Administracji LVII (1932), no 1, p. 4-23; S. PACionkowski, Problem tzw. legalnej bigamii w II RP w świetle spraw malżenskich toczonych przed Sądem Okregowym w Poznaniu, Repozytorium Uniwersytetu im. Adama Mickiewicza (2013), no. 2, p. 15-28. 


\section{Debate over the personal character of marriage law}

An attempt to eliminate this legal mosaic that enabled bigamous unions was made by the Parliament, which passed a law on the Codification Committee on 3 June 1919. The first draft marriage law was submitted by Władysław Leopold Jaworski. ${ }^{5}$ The work on the draft extended from the end of November and the beginning of December and did not make it beyond the first reading. On 2 June 1924, Karol Lustostański took up the position of the reporter, therefore the new draft of the personal marriage law was called with his name. The draft law was adopted by the Codification Committee on 4 October $1927 .{ }^{6}$ The supporters of the proposed marriage law

${ }^{5}$ The draft law provided for an optional form of marriage. However, the State was obliged to regulate the rules of contracting and dissolving marriage without regard to the internal legislation of churches and religious associations recognised by the State. The indications for invalidity and permissibility of divorce were to be harmonised for all citizens, but divorce was unavailable to Catholics who entered into a canonical marriage. The draft law entrusted jurisdiction to civil courts, but the ecclesiastical courts were able to remove spouses from the table and bed in a manner that was binding on civil authority. (See S. GŁĄB, Polskie prawo matżeńskie w kodyfikacji, Warszawa, Bibljoteka Prawnicza 1932, p. 21-31). The Catholic Church expressed his opposition towards optional civil marriages for Catholics and condemned the concept of secular marriage. It emphasized that society must not be divided into Christians and citizens, so the Church would not surrender its authority over the sacrament of marriage to the State. However, divorces were deemed contrary to Divine Law and human reason and harmful to the interests not only of the family but also society as a whole. Simultaneously, Catholics were called on to vote for parliamentarians who publicly declared that they would not allow the secularization of marriage law. Finally, the Church argued that it would not recognise secular marriages, despite the adoption of legislation making them permissible. See: J. BilczewsKi, Listy pasterskie, odezwy, kazania i mowy okolicznościowe, Lwów, Bibljoteka Religijna 1924, vol 3, p. 320-343.

${ }^{6}$ On 28 May 1929, the Committee on Work Organisation adopted a draft in an abbreviated manner, which was delivered to the Minister of Justice on 4 December 1929. On 9 December 1931, the reasons for the draft were published in print, but it was never adopted. The draft became the basis for codification work in Polish People's Republic. See: Zasady projektu prawa małżeńskiego w opracowaniu referenta głównego prof. K. Lutostańskiego, uchwalone w dniu 28 maja 1929 r., Komisja Kodyfikacyjna. Podsekcja I Prawa cywilnego, Warszawa, Komisja Kodyfikacyjna 
prepared by the Codification Committee stressed that marriage was a social institution of considerable impact on the social relations and life of Polish citizens. Therefore, also the State should have the right to determine its own system and organisation of marriage, in accordance with the ideas of modern jurisprudence, while taking into account social attitudes and the requirements of culture and civilisation, disregarding any regulations of religious nature. It was acknowledged that marriage had a profound religious significance, but when confronted by the State it was a legal construct enjoying the protection provided by it, and it was for that reason that it belonged to the state legislator to adapt marriage in accordance with its own needs and goals. ${ }^{7}$ According to Jan Gwiazdomorski, the issues of the form of marriage and divorce were to be „normalized in the same fashion for the citizens of all faiths, rather than giving the church laws of particular confessions (regulating the institution of marriage) the rank of particular law" because the legal chaos arising in the postSoviet provinces would spread throughout Poland. ${ }^{8}$

1931, vol. I, no. 3, p. 18-94, Projekt prawa małżeńskiego uchwalony przez Komisje Kodyfikacyjna w dniu 28 maja 1929, Komisja Kodyfikacyjna. Podsekcja I Prawa cywilnego, Warszawa: Komisja Kodyfikacyjna 1931, vol. I, no 1. See also: J. DwoRAS-Kulik, Prawne regulacje..., p. 200-211; L. GóRnICKI, Koncepcja i konstrukcja prawna małżeństwa w projekcie osobowego prawa małżeńskiego z 1929 r., in: Regulacje prawne dotyczace małżeństwa w rozwoju historycznym, ed. T. Dolata, Wrocław, Atut 2018, p. 171-201. Compare: J.F. GodLEwski, Problem laicyzacji osobowego prawa małżeńskiego w Polsce międzywojennej, Państwo i Prawo 22 (1967), no 11, p. 756759; P. Fiedorczy K, Unifikacja i kodyfikacja prawa rodzinnego w Polsce Ludowej na tle stosunków Państwa z Kościołem katolickim (1944-1964), in: Cuius regio, eius religio. Zjazd Historyków Państwa i Prawa, Lublin, 20-23 IX 2006 r., eds. G. Górski, L. Ćwikła, M. Lipska, Lublin, KUL 2006, p. 415-422; Idem, Wykorzystanie dorobku Komisji Kodyfikacyjnej Drugiej Rzeczypospolitej w pracach nad unifikacja osobowego prawa małżeńskiego w 1945 roku, Zeszyty Prawnicze Towarzystwa Biblioteki Słuchaczów Prawa UJ (2005), no 13, p. 89-96.

${ }^{7}$ A. Czerwiński, Problem unifikacji osobowego prawa małżeńskiego $w$ Polsce, Czasopismo Sędziowskie X (1936), no 1, p. 11-12; J. GwiAzDomorski, Trudności kodyfikacji osobowego prawa małżńskiego w Polsce, Reprint from Czasopisma Prawniczego, Kraków, Drukarnia UJ 1935, p. 176.

${ }^{8}$ J. Gwiazdomorski, Trudności..., p. 176. 
Conservative circles rejected Lutostański's draft using the mass media. The greatest amount of controversy in the right-wing conservative circles was caused by the provision allowing the form of marriage to be chosen. On account of protests, extensive works were written, mainly intent on criticising civil marriage, which conservatives assume to be promoting widespread divorce. ${ }^{9}$

In response to Lutostański's project, another draft marriage law was developed by Z. Zygmunt Lisowski and another one by Jerzy Jaglarz. Lisowski's draft envisaged introducing a religious type of marriage throughout Poland ( $\$ 6$ ) and civil marriages of necessity $(\$ 7)$. Civil jurisdiction was exercised by ecclesiastical courts and, on the basis of regulations of the religious law, they adjudicated on the nullity of a marriage ( $\$ 45 \mathrm{ff}$. ) or its dissolution ( $\$ 102 \mathrm{ff}$.$) . Civil$

\footnotetext{
${ }^{9}$ In the Address of the Bishops of Poland, the Catholic bishops asked representatives of the government and parliamentary circles (Catholics) to guarantee a sacramental character to Catholic marriages, invoking the sanctity of family life and the stability and prosperity of the life of the Nation and State. They stressed that a marriage contracted before a civil registrar was invalid because it contravened Divine Law (See: Odezwa Biskupów Polski do Rzadu i Narodu w obronie Sakramentu Małżeństwa, Wiadomości Diecezjalne Podlaskie 8 (1926), no 3, p. 81-82). In the address, dealing with the draft marriage law, the Catholic bishops, referring to the Encyclical on Christian Marriage of Pope Pius XI of 31 December 1930 and Article 114 of the March Constitution, yet again demanded that the sacred character of Catholic marriages be safeguarded. At the same time, they complained about the principle of indissolubility of marriage being trampled upon and the introduction of temporary marital unions, which in the opinion of the Bishops of Poland brought Poland closer to Bolshevik Russia. See: W sprawie projektu ustawy o małżeństwie. Orędzie Episkopatu Polski, Miesięcznik Kościelny dla Archidyecezyi Gnieźnieńskiej i Poznańskiej 46 (1931), no 11, p. 206-207). See also: D. Szczepaniak, Stanowisko kościoła katolickiego w Polsce wobec projektu osobowego prawa małżeńskiego Karola Lutostańskiego, Kortowski Przegląd Prawniczy 2 (2015), no 2, p. 96-104; A. WoźNICZEK, Rozbiór krytyczny małżeństwa. Spory o kodyfikacje prawa małżeńskiego w II RP, Więź (2011), no 5-6, p. 132-141; S. BISKUPSKI, Reforma prawa małżeńskiego $w$ Polsce, Reprint from Ateneum Kapłańskie vol. 25 (1930), p. 13-39; Idem, O nowe prawo małżeńskie w Polsce, Włocławek, Diecezjalny Instytut Akcji Katolickiej 1932.
} 
courts have only ruled on the civil effects of marriage. ${ }^{10}$ Jaglarz's draft law combined the features of both of the above-mentioned drafts. It envisaged a religious form of marriage (Article 27ff.) and the jurisdiction of ecclesiastical courts in nullity cases (Article 41ff.); however, the oversight of the jurisdiction of ecclesiastical courts to rule on particular cases was entrusted to the state authorities (Article 43). Adjudication in divorce cases was entrusted to common courts (Article 64). ${ }^{11}$

\section{Dispute over the form of marriage celebration}

In the opinion of doctrine representatives strongly connected with the Church, it was argued that civil marriages deprive religious marriages of legal consequences; moreover, the freedom of choice contributed to the equal status of these two institutions and divorce getting more popular. What is more, the secularization of marriage make religious indifference spread further, creating opportunities to live in an immoral way. It also caused tensions between the faithful and the Church. ${ }^{12}$ Stanisław Biskupski argued that religious marriage is not about the compulsion to belong to the Church, but about

\footnotetext{
${ }^{10}$ See: Prawo małżeńskie (projekt ustawy), edited by Z. Lisowski, Poznań published by the author 1934; K. MiKA, Matżeńskie prawo osobowe w projekcie Zygmunta Lisowskiego z 1934 r., in: Prawo blisko człowieka. Z dziejów prawa rodzinnego i spadkowego, ed. M. Mikuła, Kraków, UJ 2007, p. 79-85.

${ }^{11}$ J. JAGLARz, Projekt prawa małżeńskiego, in: Problem kodyfikacji prawa małżeńskiego w Polsce, Poznań, Dziennik Poznański 1934, p. 47-71; K. Krasowski, Próby unifikacji osobowego prawa małżeńskiego w II Rzeczypospolitej, Kwartalnik Prawa Prywatnego III (1994), no. 3, p. 467-487.

${ }^{12}$ S. Biskupski, Reforma...., p. 25. Władysław Abraham argued that the introduction of secular marriages would not rule out the possibility of getting married using the church form, but made them inconsequential in terms of civil legislation, making them of secondary importance and restricting to a purely private sphere, which was contrary to the existing custom of regulating marital matters by the Church. He also claimed that the optional form of marriage was at odds with the principles upheld by the Catholic Church, since it led to the exclusion of religious marriages as superfluous (See: W. AвR Aнам, Zagadnienie kodyfikacji prawa matżeńskiego, Lwów published by the author 1927, p. 3-10).
} 
Catholics committing themselves to the religious form of marriage by being voluntary members of the Church. ${ }^{13}$ However, he believed that it was possible to neutralize the rules on the secular form of marriage by explaining to the faithful that the civil marriage was only a formality for the State, imparting civil-law significance on a marriage celebrated in the Church. Also, he deemed civil marriages permissible only for acatholics and the non-religious. Adam Czerwiński held a different opinion, considering that the draft marriage law should only allow compulsory civil marriages, leaving to the spouses the freedom to reaffirm their marriage in the Church by celebrating it in the religious form, which would be of no consequence to the state authority, to merely satisfy the spiritual longing of the spouses. He argued that the optionality of the form violates the uniformity of law and is the basis of demonstrations, exemplified by the political dispute surrounding the draft marriage law. In his opinion, only the introduction of civil marriages as binding on everyone „will put an end to protests for the future."14

Lutostański responded to the attacks ${ }^{15}$ by providing counterarguments, and referring to the pastoral letter of the primate of Poland of 23 April 1932, which stigmatized lie, demagoguery, slander, insincerity, and low-quality discussion and polemics. The situation was also commented on by the chairman of the Commission,

\footnotetext{
${ }^{13}$ S. Biskupski, Reforma...., p. 36-38.

${ }^{14}$ A. Czerwiński, Problem..., p. 13-16.

${ }^{15}$ See: K. Lutostański, O metodach stosowanych w polemice $z$ Projektem Prawa Matżeńskiego Komisji Kodyfikacyjnej, Gazeta Sądowa Warszawska LX (1932), no 21, p. 289-292; Idem, Uwagi z powodu projektu pracy L. Domańskiego „O małżeństwie”, Gazeta Sądowa Warszawska LX (1932), no 37, p. 525-530, no 38, p. 541, no 39, p. 557-562. The author also referred to the issue of divorce, pointing out that in times of divorce-free legislation there was a widespread deterioration of morals. In his opinion, the rejection of divorce made this provision defunct, causing citizens to disregard and bypass it, which made the law lose its regulatory and control function. He stressed that neither an order nor a legal ban had a direct impact on the morals of society, and opponents of divorce were mistaken in seeking in them the cause of adultery, corruption of morals, misunderstanding between spouses, illegitimate children, free relationships or suicide.
} 
Emil Stanisław Rappaport, who held the position that the draft law developed by Lutostański did not endorse any of the extreme positions, as it was based neither solely on the provisions of canon law nor strictly on secular law. He tried to integrate all aspects of Polish social and political life and expectations of the public. He emphasised that the Codification Committee was guided by the conviction that the regulation of the entire marriage law rested with a sovereign state, which was committed to the principle of civic equality regardless of religion or gender, freedom of conscience, and therefore the jurisdiction was entrusted to the state courts. ${ }^{16}$

\section{Dispute over divorce and separation}

In Lutostanski's draft, a marriage would cease upon the death of either spouse or by the dissolution of the marital community, which was a variant of separation, or by granting divorce. ${ }^{17}$ However, according to Czerwiński, the institution of marriage was justified only in the marriage law, which did not allow such a separation as a substitute for divorce. Separation was pointless if the marriage law permitted divorce, since the separation of marriage was essentially a limited divorce, since the marital community was severed. The spouses were relieved of their mutual obligations. So the marriage still existed in the eyes of law, but only formally, because it no longer served its purpose. Czerwiński added that separation made further existence of marriage abstract since it had no reflection in real life. ${ }^{18}$

\footnotetext{
${ }^{16}$ E.S. Rappaport, Z Komisji Kodyfikacyjnej, Ruch Prawniczy, Ekonomiczny i Socjologiczny IX (1929), p. 925-926; E. Neymark, Z Komisji Kodyfikacyjnej. Reforma prawa małżeńskiego; Ruch Prawniczy, Ekonomiczny i Socjologiczny IX (1929), p. 578.

${ }^{17}$ See: article p. 54-80 of Lutostanski's draft law. See also S. BISKUPSKI, Rozwody w projekcie prawa małzeńskiego Komisji Kodyf. Rz. P., Ateneum Kapłańskie 17 (1931) vol. 28, no 3, p. 275-282; P. KASPRZYK, Trudności kodyfikacyjne związane z wprowadzeniem instytucji Separacji małżeńskiej do prawa polskiego, Studia z Prawa Wyznaniowego 2 (2001), p. 27-56.

${ }^{18}$ See: A. Czerwiński, Problem unifikacji osobowego prawa małżeńskiego $w$ Polsce, Czasopismo Sędziowskie X (1936), no 2, p. 65-671. The author also pointed out that divorces were known in Polish law in the early nineteenth century, as the uniform
} 
Its prolonged existence no longer had any purpose, so separation was different from divorce (or dissolution of the marital bond) only in that the spouses could not remarry. Jan Przeworski was also an opponent of separation. He pointed out that this institution was a necessary evil due to the lack of other way of dissolving a marriage. In practice, it caused resentment, aversion and hatred for the other spouse due to the impossibility of starting a new life and therefore usually practising permanent cohabitation. Separation would destroy the morality of two persons, because the only way out was the death of one of the spouses. ${ }^{19}$

The law proposed by Lutostański out of concern for the permanence of marriage and for reasons of public interest provided for the involvement of the public prosecutor in nullity cases and cases for substituting divorce for separation. The draft law that the prosecutor be served the statement of claim for the annulment and the summons to court hearings. The final sentence of the civil court was binding on both parties and retained its force in relation to third parties. The prosecutor could adduce evidence and make submissions. A sentence was handed down after they were heard. The prosecutor's support for the application for marriage annulment implied continuation of the case in spite of the continued absence of the parties to the case. The parties could not claim a reimbursement for his appearance. The reason for requesting an annulment was a defective declaration of will that was made when the marriage was entered into, an error about the person, compulsion and fear, and if a certificate of absence of obstacles has not been presented, unless the claim concerned a church marriage. The annulment of a marriage produced the same effect as a divorce, but was treated as a more severe measure intended to

French law applicable in the Kingdom of Poland and then Russian law until 1836 provided for divorce for all citizens regardless of their religion. However, the marriage law of 1836 placed the Orthodox faith in a privileged position, which permitted divorce.

${ }^{19}$ J. Przeworski, O przyszłym prawie małżeńskim w Polsce, Palestra III (1926), no 12, p. 534. 
secure the public interest. Divorce, which was used to protect the private interests of the parties, was regarded as a more lenient way of breaking marital ties. The separation of the spouses could only take place by a judicial decision. ${ }^{20}$

According to the conservative circles, the indissolubility of marriage was the basis for the permanence of the family and the foundation of the permanence of the State. Therefore, granting divorce even in a few and specified cases resulted in an increased number of divorces, becoming a social plague on a scale greater than the population growth. Difficulty in obtaining a divorce were thought to be a fiction. It was stressed that separation within the meaning of the draft law was a prelude and transitional state to a divorce, which was then to take place without any legal restrictions, as the criteria enabling one to request separation were so extensive that they encompassed „all setbacks and conflicts of everyday life in matrimony." 21

${ }^{20}$ The reasons for granting divorce were: adultery, threatening the spouse's life, grave insults and slanders, provided that no more than three years or six months have passed since the occurrence or becoming aware of such circumstances, as well as an error or compulsion. The application was time-barred within 6 months after the spouse became aware of the error or cessation of coercion. An indirect system of evidence was allowed. The judicial decision was based on the will of the spouses.

${ }^{21}$ S. Biskupski, O nowe prawo..., p. 31-40. Biskupski emphasized that divorces defied natural law, causing incalculable damage and breaking communion with the Church. Further on, he pointed out that divorces should be treated as a violation of the natural rights of the family and one of the reasons for the breakdown of specific societies, whereas he thought indissolubility of marriage to be the mainstay of humanity. Stanisław Trzeciak spoke in a similar vein, when comparing the draft marriage law with the Bolshevik code on marriage. At the same time, he pointed out that seeing marriage not as a sacrament but as an ordinary contract - a civil status record, which could be easily broken off without providing any reasons, led to dehumanisation of family life and destruction of the Church. He emphasized that a woman was reduced to a toy at a civil wedding that a man could get rid of at any time (S. Trzeciak, Talmud, bolszewizm i „projekt prawa małżeńskiego $w$ Polsce”, Warszawa, Drukarnia Archidiecezjalna 1932, p. 32-33, 49). 


\section{Dispute over the jurisdiction in matrimonial cases}

The draft law proposed by Lutostański did not introduce any restrictions on marrying people of other faiths in accordance with the constitutional principle of freedom of conscience and religion, and - importantly for the issues related to divorce migration at the time - provided for civil jurisdiction of common courts. The authors of the draft marriage law took the position that cases arising in the context of marriage law are civil cases and therefore are dealt with by common courts and the Supreme Court in accordance with Article 85 of the Constitution. At the same time, it was stressed that every citizen had the right to a trial and that no law could take away the possibility of bringing one's claim to the court. However, according to the conservative circles, the consequence of entering into a religious marriage was that the State handed over the jurisdiction over the dissolution of marriage, separation, or marriage annulment to ecclesiastical courts. The supporters of such a solution stressed that the ecclesiastical courts did not rule on matters concerning property or succession consequences of a marriage, and therefore did not interfere with the powers of state authority, nor did they violate the idea of state sovereignty. ${ }^{22}$ It should be pointed out, however, that the practice of ecclesiastical courts adjudicating in disputes arising out of a marriage relationship in interwar Poland, including adjudication that abused the powers granted by the State and mutual non-recognition of sentences handed down by consistories and re-adjudication in the same cases, raised problems under civil law when ruling on the legal effects produced by marriages, including bigamous ones. ${ }^{23}$

The discussion concerning matrimonial jurisdiction was enriched by Gwiadomorski, who argued that jurisdiction could be transferred to the ecclesiastical courts only if the State clearly defined

\footnotetext{
${ }^{22}$ M. Aвraham, Zagadnienie..., p. 20-24. Abraham pointed out that the competence of ecclesiastical courts to adjudicate in matrimonial cases as matters of the sacrament was a direct result of the concordat and the constitution.

${ }^{23}$ For more on this, see: J. Dwor as-Kulik, Prawne regulacje..., p. 166-198, Idem, Przyczyny i skutki legalnej bigamii..., p. 116-121.
} 
the competence by means of statute and provided for a sanction safeguarding adherence to state regulations. ${ }^{24}$ Stanisław Gołąb, on the other hand, indicated that the law binding on prospective spouses at the time when their marriage was being concluded should be made binding for the whole duration of their marriage. The State should reserve for itself the judiciary for matrimonial cases, because it did not infringe on the ecclesiastical judiciary. ${ }^{25}$ Civil courts would rule on the effects of a marital union entered into, but would not declare nullity of religious marriages (Article 24 of Lutostanski's draft law). A spouse who had completed the religious formula after getting married before a civil registrar could, in the case of a divorce granted by a civil court, claim the nullity of his or her marriage before an ecclesiastical court. Gwiazdomorski also voiced his opinion in this regard, saying that the competent court to rule on the validity and separation of a marriage or on replacing separation with divorce should be the district court with jurisdiction over the last common residence of the spouses in Poland, which would be the permanent residence of at least one of them, or in the absence of such common residence this would be the district court of the district where the defendant resided or stayed, or of none of the above was true, this would be the court in Warsaw. ${ }^{26}$ Such a solution was endorsed also by Włodzimierz Dbałowski, who argued that a judge was under the obligation of impartiality and political neutrality, which compelled him to adjudicate within the limits of state legislation regardless of his own national and religious convictions. ${ }^{27}$ Czerwiński took a similar

\footnotetext{
${ }^{24}$ Gwiazdomorski also pointed out that under such circumstances state courts would have to attach a validity clause to decisions made by ecclesiastical courts after establishing the substantive validity of such decisions, which in practice would deprive ecclesiastical courts of their jurisdiction over matrimonial cases (See: J. Gwiazdomorski, Trudności..., p. 190-191).

${ }^{25}$ S. GŁĄB, Reforma prawa małżeńskiego w Polsce, Głos Adwokatów VI (1931), no. 11, p. 245.

${ }^{26}$ J. GWiazDomorski, Trudności..., p. 75-76.

${ }^{27}$ W. Dваєоwsкi, Na marginesie projektu prawa małżeńskiego, Gazeta Sądowa Warszawska LX (1932), no 6, p. 71-72.
} 
stance, arguing that ecclesiastical courts should be treated as alien courts as they were not supervised by the State, but were subject only to higher church authority. Furthermore, civil courts dealt with matrimonial cases only with regard to their civil effects, without assessing them on the basis of their religious nature, which helped to preserve independence between the State and church jurisdiction. ${ }^{28}$

\section{Conclusion}

The fragmentation of the personal matrimonial law in the former partitions, its obsolescence and backwardness, plus divisions within the society revealed by the disputes surrounding the nature of marriage law, triggered many dangerous phenomena, such as legal bigamy, above all. ${ }^{29}$ The courts with jurisdiction to rule on matrimonial cases abused the competence they were granted by the State, thus contributing to the legislative crisis in the area of marriage law. Owing to disregard for state regulations and the impossibility of enforcing them by the State, thus leading to the duplication of court sentences through mutual adjudication in the same cases concerning dissolution

${ }^{28}$ A. Czerwiński, Problem..., p. 74-75. According to Czerwiński, in the 1925 Concordat the Holy See did not demand that the administration of civil justice be abolished in matrimonial cases, so the draft marriage law rightly introduced a uniform jurisdiction in the whole of Poland.

${ }^{29} \mathrm{H}$. Świątkowski described the period of interwar Poland by saying: „The greatest confusion in divorce practice existed in the former Russian district. Only for very wealthy people was it possible to obtain a divorce in episcopal tribunals, which was disguised as marriage annulment. The middle-income social groups pursued a different path: change their religion and get a divorce in one of the non-Catholic consistories, which governed themselves by their own internal canonical law. Changing one's confession for divorce purposes became commonplace. It was a kind of first and second-class divorce, but even so the second method was expensive, too. Not everyone could afford it. The third class - the impecunious - was nothing to write about. Here, marital matters in the countryside were often settled by arsenic and axe, whereas in the city they were settled informally, simply by abandonment or cohabitation, without any options to protect the interests of the woman and her child" (See: H. Św Į̇Tко кski, Z dziejów walki o świeckie prawo małżeńskie w Polsce, Argumenty III (1959), no 22, p. 8). 
or annulment, the introduction of jurisdiction of ecclesiastical courts in the whole of Poland would spread the chaos existing in the former Russian partition to the entire territory of the state. For that reason, despite Catholicism as the predominant religion of interwar Poland, only the introduction of civil jurisdiction in matrimonial cases could prevent deviant behaviours arising at that time and its consequences under the property or inheritance law. The Lutostanski proposal assumed the equality of all citizens before the law, regardless of religion or gender, and it was therefore impossible, by compromise, to grant matrimonial jurisdiction only the Catholic Church to the exclusion of other confessions recognised by the State. Under the pressure of the public opinion, especially from the conservative circles opposing the draft personal matrimonial law adopted by the Codification Committee, the government withheld it for a long time at the Subcommittee level, and finally decided not to implement it as the basis for the marriage law in Poland. Marriage law was not unified until the outbreak of the war, because the Codification Committee considered the case closed and its work on it final. The consequences of non-unification of marriage law were still felt in the time of Polish People's Republic (PRL).

\section{Debate over secularisation of the marriage law in the Second Polish Republic}

The legal mosaic inherited from the partitioning states gave rise to dangerous phenomena, legal bigamy above all. Two conflicting political blocs - the secular and the ecclesiastical one - prevented the personal marriage law from being codified in the interwar period, which would have prevented further deterioration of legal chaos gnawing at the ancient foundations of the state, i.e. marriage and family. The aim of this article is to describe - using the historical and legal method - the most important aspects of dispute that emerged when attempts were made to unify marriage law in the lands of the Second Republic, as well as making reference to the arguments of the parties to the dispute concerning the choice of marriage 
form, jurisdiction in matrimonial cases and the possibility of dissolving a marriage by divorce.

SŁOWA KLUCzowe: projekt Lutostańskiego; śluby cywilne; Komisja Kodyfikacyjna; forma zawarcia małżeństwa; rozwiązanie małżeństwa; sądy wyznaniowe

KeYwORDS: Lutostański draft law; civil marriage; Codification Committee; form of marriage celebration; dissolution of marriage; ecclesiastical courts

\section{INFORMATION ABOUT THE AUTHOR}

Dr Judyta Dworas-Kulik - Katedra Historii Ustroju i Prawa, Instytut Nauk Prawnych, Wydział Prawa, Prawa Kanonicznego i Administracji, Katolicki Uniwersytet Lubelski Jana Pawła II. 